\title{
Medicina integrativa e a biopolítica da pandemia
}

Renato Sampaio de AZAMBUJA: Grupo Hospitalar Conceição. ORCID: https://orcid.org/00000003-2039-4732

\section{Resumo}

Esse texto vincula-se a tese de doutorado que desenvolvo no PPG em Educação em Ciências UFRGS. Nele, trago situações e aspectos sócio-políticos e econômicos gerados pela pandemia atual para pensar o corpo e o cuidado no processo saúde/doença no âmbito da biomedicina e discutir possibilidades de práticas médicas integrativas. Trata-se de um estudo teórico que utiliza ferramentas foucaultianas. A pandemia vem alterando nossos hábitos, despertando uma gama de sensações e atitudes, especialmente em relação à morte. Cotidianamente a mídia veicula uma rede discursiva de práticas que visam a disciplinarização dos corpos e mentes através do saber especializado. A dinâmica da relação vital entre o coronavírus e os seres humanos alcança maquinismos sociais, econômicos e políticos, entre eles o déficit estrutural na saúde: a má distribuição de profissionais da saúde e de leitos hospitalares. O descaso histórico com a saúde pública torna-se visível num atendimento precário. Vida e a morte limitam-se ao déficit de respiradores artificiais na e insuficiência de equipamentos de proteção aos profissionais de saúde. Para o "combate", a biomedicina preconiza estratégias de higiene, distanciamento físico e isolamento, depositando "esperança" na busca por vacinas através da modificação viral pela engenharia genética. Nesse cenário torna-se exposta a noção foucaultiana de que o corpo vivo e portanto sujeito à morte é o objeto fundamental da ação biopolítica: a tarefa é a produção de um tipo de corpo disciplinado e docilizado. Fabricar um corpo significa produzir saberes que se transformam em dispositivos para um conjunto de tecnicas pelas quais o poder governa a vida e a morte de sujeitos e populações. Tratam-se de técnicas de governo na gestão da vida como uma rede de poder que se capilariza na totalidade das relações sociais até implicar efeitos no corpo individual. Vê-se em funcionamento uma política de controle. A biomedicina revela um corpo sujeitado às verdades científicas, as

Recebid o: 2 out. 2020

Aceito: 21 out. 2020

Autor de correspondência: Renato Sampaio de Azambuja renatodeazambuja@gmail.com

Conflito de interesses: O autor declara não haver nenhum interesse profissional ou pessoal que possa gerar conflito de interesses em relação a este manuscrito. quais não emergem das experiências do sujeito doente, mas do saber médico especializado. Como prática discursiva histórica, a biomedicina tende a gerar efeitos nos quais as pessoas se subjetivam enquanto corpos estruturados em órgãos, existindo independentemente dos contextos onde se processam suas relações e suas historicidades. $\mathrm{Na}$ correção do corpo e maximização da vida, cria verdades universais balizadas pela ciência objetiva e impessoal e associa-se à indústria farmacêutica. $O$ enfrentamento proposto pela biomedicina à pandemia vem sendo: saber muito sobre a patologia orgânica e pouco sobre o estado emocional vivido na singularidade do sofrimento. Todavia, a pandemia escancara seus efeitos: pode-se chamar de espaço-tempo político, social e cultural: não afeta igualmente os segmentos da população. Os grupos sociais empobrecidos, com condições de moradia, trabalho, transporte, alimentação e cuidados precários, sofrem de forma mais aguda os efeitos da pandemia: as estratégias de controle da doença podem significar perda de emprego ou redução de salário. As condições inseguras de vida de moradores de rua, idosos e portadores de deficiências, moradores em asilos, são grupos cujos riscos transcendem suas biologias. Grupos que dificilmente obterão acesso às estratégias terapêuticas propostas pela biomedicina. Outrossim, afora a vigilância e disciplina, a constante ameaça da morte gera a suspeita acerca do outro e vê a doença como inimiga e 
não como processo da vida, no qual o adoecer integra as experiências e condições existenciais dos sujeitos. Emerge o paradoxo de evitar a morte de alguns e de deixar morrer a outros, aqueles desnecessários e inconvenientes ao sistema. Revela-se uma faceta das estratégias necropolíticas. Reduzidas à coisa biológica, algumas pessoas podem ser "esquecidas" para morrer, desconsiderando-se suas histórias singulares, base potencial de suas suscetibilidades individuais para adoecer. Ao alimentar o medo, alimenta-se o ódio e a ausência de compassividade, confunde-se o limite da morte, sua presença constante e sua negação, tornam-se, todos, fonte de estratégias biopolíticas. Por outro lado, pandemia mostra a produção de uma rede de relações capaz de perturbar o corpo, a atitude e a vida em vulnerabilidades compartilhadas, ao mesmo tempo em que singularmente experimentadas por cada um em seu território existencial. Faz pensar num corpo implicado e suscetível na relação com o outro, não somente orgânico e individual, mas constituído em um movimento existencial que é transindividual. Coloca a perspectiva de corpos e subjetividades coletivamente constituídos, mutuamente agenciados. Porém, ao serem sujeitadas ao biopoder de gestão do corpo e da vida, através das técnicas biomédicas, as pessoas não encontram espaço para suas experiências singulares de adoecimento. Implicado às suscetibilidades individuais, geralmente desconsideradas pelas práticas biomédicas, o adoecer pelo COVID pode se mostrar assintomático, brando ou grave, com tendência a apresentar sequelas - vasculares, neurológicas, oculares, respiratórias, entre outras. Outras práticas médicas, que defendem uma perspectiva integrativa de corpo/mente, podem trazer diferentes estratégias de cuidado voltadas para o equilíbrio dos processos existenciais, diminuindo a suscetibilidade ao adoecer e, caso adoecer, que a enfermidade possa transcorrer de forma benigna. No cenário atual, nada sabemos das experiências subjetivas daqueles que adoecem gravemente e de suas diferenças dos que quase não manifestam sintomas. Não sabemos os motivos do coronavírus afetar tão diferentemente os corpos. A biomedicina oferece a explicação imunológicas e genética. Minha proposição é alargar tal compreensão e buscar nas histórias cartográficas dos sujeitos sua suscetibilidade: as medicinas integrativas oferecem tal possibilidade. A implementação, no sistema de saúde, de políticas e práticas integrativas de saúde pode abrir caminhos para a diminuição dos custos, para práticas de cuidado alicerçadas na singularidade do sujeito e no cuidado de si, para produção de técnicas de cuidado transformadoras alicerçadas em corpos existenciais, cujo viés biológico é somente uma das facetas do si mesmo. Assim, a pandemia suscita condições para um novo umbral de relações humanas que podem proporcionar a produção de saberes médicos e de cuidado voltados ao estudo da relação mente/corpo como possibilidade para outras tecnologias em saúde.

Descritores: Sistema Único de Saúde; Medicina Integrativa; Pandemias.

Keywords: Unified Health System; Integrative Medicine; Pandemics.

Palabras-claves: Sistema Único de Salud; Medicina Integral; Pandemias. 